\title{
Sciendo
}

DOI: 10.1515/aon-2018-0011

\author{
JANUSZ ĆWIKLAK ${ }^{1)}$, \\ STEPAN SAVCHUK ${ }^{1)}$ \\ SOFIYA DOSKICH ${ }^{2)}$ \\ 1) Polish Air Force University, Poland \\ 2) Lviv Polytechnic National University, Ukraine
}

\section{REMOVING THE INFLUENCE OF NETWORK EFFECT ON LOCAL POSITION SOLUTION}

\begin{abstract}
To investigate and remove the network effect to the national GNSS network the results obtained from three GNSS networks which are tied to ITRF2008 using minimal constraints were compared. The first network is the EUREF Permanent Network (EPN), the second is EPN subnetwork processed by WUT LAC (WUT), the third is exactly Ukraine reference network (URN). The position differences between these networks - EPN and URN (WUT and URN) can reach 9.1 (6.6) mm for X, 4 (3.8) $\mathrm{mm}$ for $\mathrm{Y}$ and 11.7 (12.2) $\mathrm{mm}$ for Z. To obtain consistent station positions and velocities without network effect two weekly solutions were combined. The results demonstrate that the network effect on the local solution (Ukraine reference network) can be eliminated. This approach is valid because the same data analysis strategy was applied during both network processing.
\end{abstract}

\section{Keywords:}

GNSS networks, influence of network effect, cumulative solution, local network

\section{INTRODUCTION}

According to [Legrand, Bruyninx, 2009] network effect can induce biases in the position solutions obtained from a regional GNSS network when tying it to a global reference frame using minimal constraints [Altamimi, 2003]. Global solutions are much more stable and less sensitive to the reference frame definition compared to 
regional solutions [Legrand, Bruyninx, Bergeot, 2010]. In regional networks, the network effect has a significant influence on the estimated velocity and might cause wrong geodynamical interpretations [Legrand, Bergeot, Bruyninx, Wöppelmann, Bouin, Altamimi, 2010]. Therefore, to obtain consistent set of station positions of regional network without influence of network effect global and regional network solutions should be combined. As global and regional solution we usually mean and accept the combined solutions from IGS and EPN networks. The main goal of our research is to remove the network effect from the national GNSS network of Ukraine (local solution), so for this task it was better to accept combined solution from EUREF Permanent Network (fig. 1) as global solution. With this step, we would be able to increase the number of Ukrainian stations in the process and as a result increase the accuracy of the local solution.

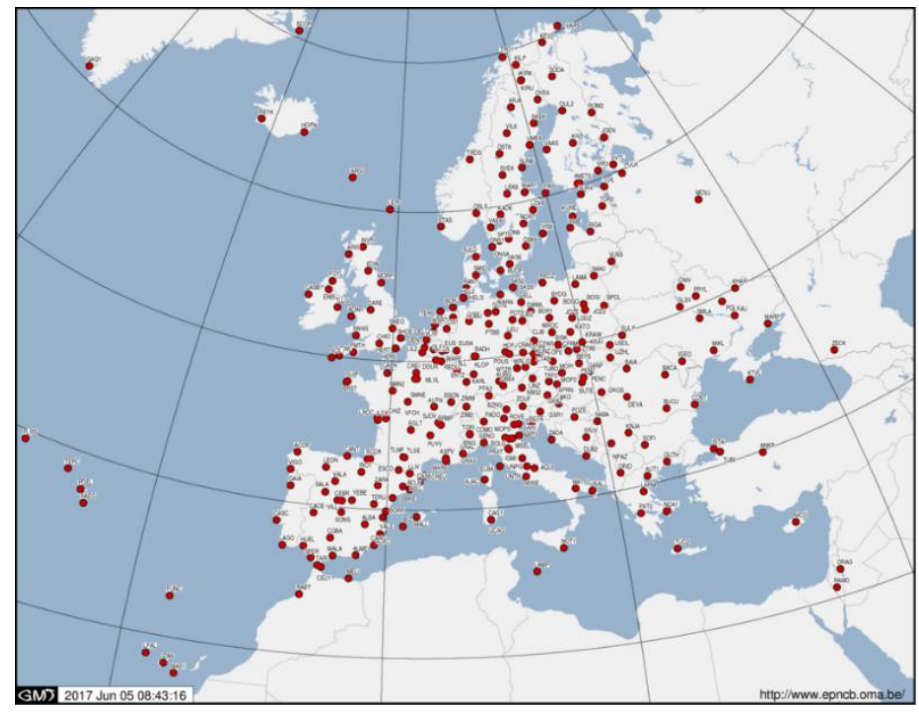

Figure 1. EUREF Permanent Network (EPN)[7]

The EUREF Permanent GNSS Network includes 4 segments: the first is continuously operating GNSS reference stations, the second is data centres which providing access to the station data, the third is analysis centres that routinely analyze the GNSS data and the last is product centres or coordinators that generate the EPN products. The EPN is divided in well-defined subnetworks which are separately processed by sixteen EPN Analysis Centres (ACs) following the rules and guidelines set up by the International GNSS Service and supplemented by the EUREF Technical Working Group. One of these Analysis Centres is located in Warsaw University of Technology 
(Poland, Warsaw). Warsaw University of Technology (WUT) has been EUREF Local Analysis Centre since January 1996. WUT LAC submits to EUREF weekly and daily results of its EPN subnetwork, which is mainly composed of stations located in Central Europe. WUT LAC is also the closest Analysis Centre to the borders of Ukraine.

Also, many countries in Europe in addition to stations that included in EPN have their own networks of reference GNSS stations (local networks). These networks define the geodetic reference system in their countries. Ukraine has such national network of reference GNSS stations and significant part of them is being processed in WUT LAC. So for our research we accepted solution from EPN subnetwork processed by WUT LAC as regional solution. To obtain consistent set of station positions of local network without influence of network effect we decided to combine global (regional) and local network solutions.

\section{DATA AND NETWORKS}

As mentioned above input data for research is cumulative solutions of the three networks. The global network - EUREF Permanent Network (fig. 1) which containing 321 stations. The regional network - EPN subnetwork processed by WUT LAC(fig. 2) which containing 124 stations and the local network - Ukraine reference GNSS network (fig. 3) which containing $~ 150$ stations. Global and regional networks have been computed using the Bernese software [Dach, Hugentobler, Fridez, Meindl, 2007]. Local network have been computed using the Gamit-Globk software [Herring, King, McClusky, 2009]. The solutions have been expressed in ITRF2008 under minimal constraints using 7 transformations parameters. The attempt in the processing was to use similar strategy and models in both software.

Table 1. The comparison of GAMIT and BERNESE strategy

\begin{tabular}{|l|l|l|}
\hline \multirow{2}{*}{ Option } & \multicolumn{2}{c|}{ Software } \\
\cline { 2 - 3 } & \multicolumn{1}{c|}{ GAMIT-GLOBK } & \multicolumn{1}{c|}{ Bernese } \\
\hline Input data & RINEX & RINEX \\
\hline Orbits & Final IGS & Final IGS \\
\hline Antenna model & IGS08_wwww.atx & IGS08_wwww.atx \\
\hline Ocean loading & FES2004 & FES2004 \\
\hline Troposphere & Saastamoinen & GPT \\
\hline Mapping function & VMF1 & GMF \\
\hline
\end{tabular}

Source: Authors. 


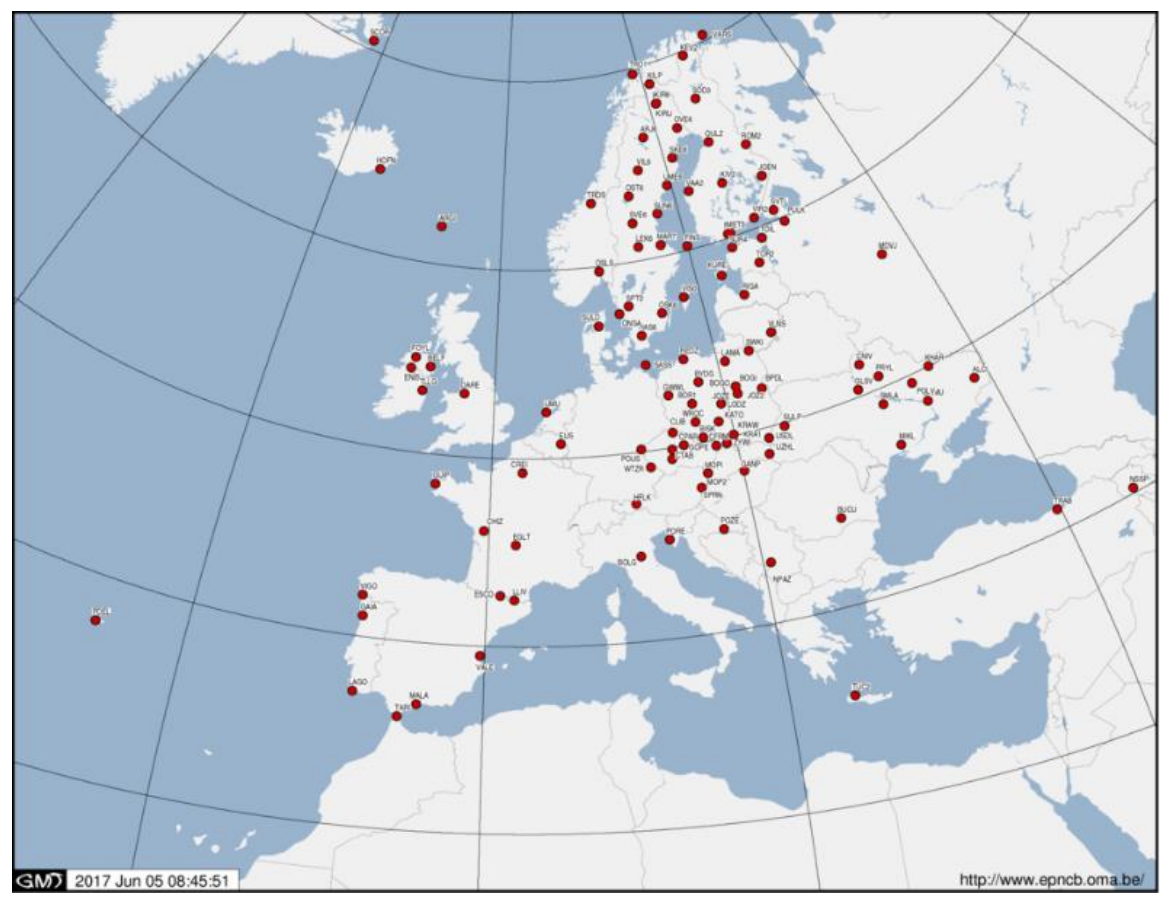

Figure 2. EPN subnetwork processed by WUT LAC (WUT) [8]

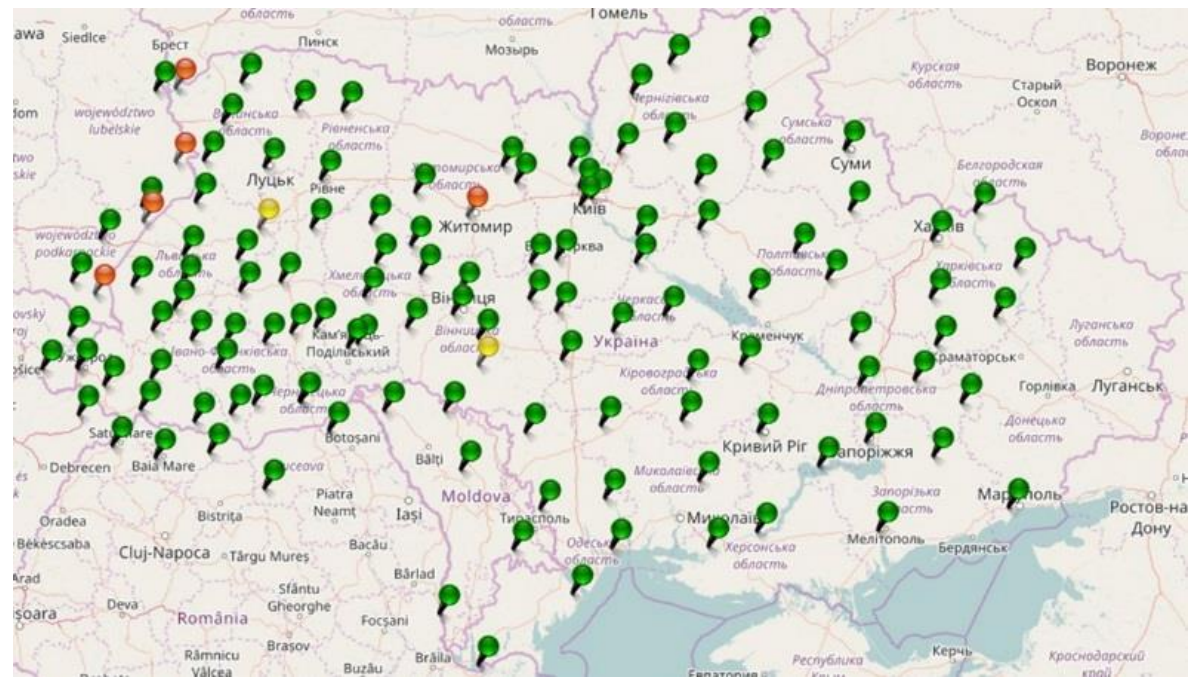

Figure 3. Ukraine reference network. Source: Authors. 


\section{RESULTS AND ANALYSIS}

Since different software packages were used to generate global (regional) and local solutions, we will investigate their differences and accuracy. This must be done to find out whether we could use various software packages for removing network effect. For this task all stations of EPN subnetwork processed by WUT LAC for one week (1922 GPS week) were estimated in Gamit-Globk software. Differences between the two solutions provided in Fig. 4.

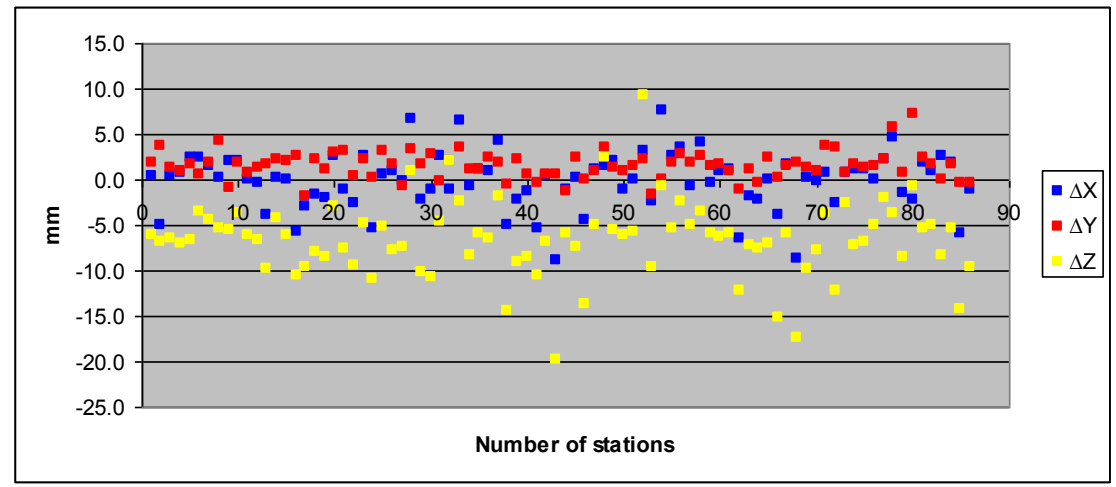

Figure 4. Differences between Bernese and Gamit-Globk solution. Source: Authors.

Table 2. Statistics (maximum, mean and RMS) of the differences between Bernese and Gamit-Globk solution.

\begin{tabular}{|c|c|c|c|}
\hline \multirow{2}{*}{ Differences between } & \multicolumn{3}{|c|}{ GAMIT-BERNESE } \\
\hline Positions, mm & Max & Mean & RMS \\
\hline X & 7.5 & -0.2 & 3.1 \\
\hline Y & 7.1 & 1.5 & 1.5 \\
\hline $\mathrm{Z}$ & 9.3 & -6.6 & 4.2 \\
\hline
\end{tabular}

Source: Authors.

Since RMS is within $5 \mathrm{~mm}$, we could combine the solutions of this software packages (global and local). To remove the network effect, we first have to find the value of this error. For this task we calculated the differences (fig 5) between global, regional (EPN, WUT) and local (URN) networks solutions. 

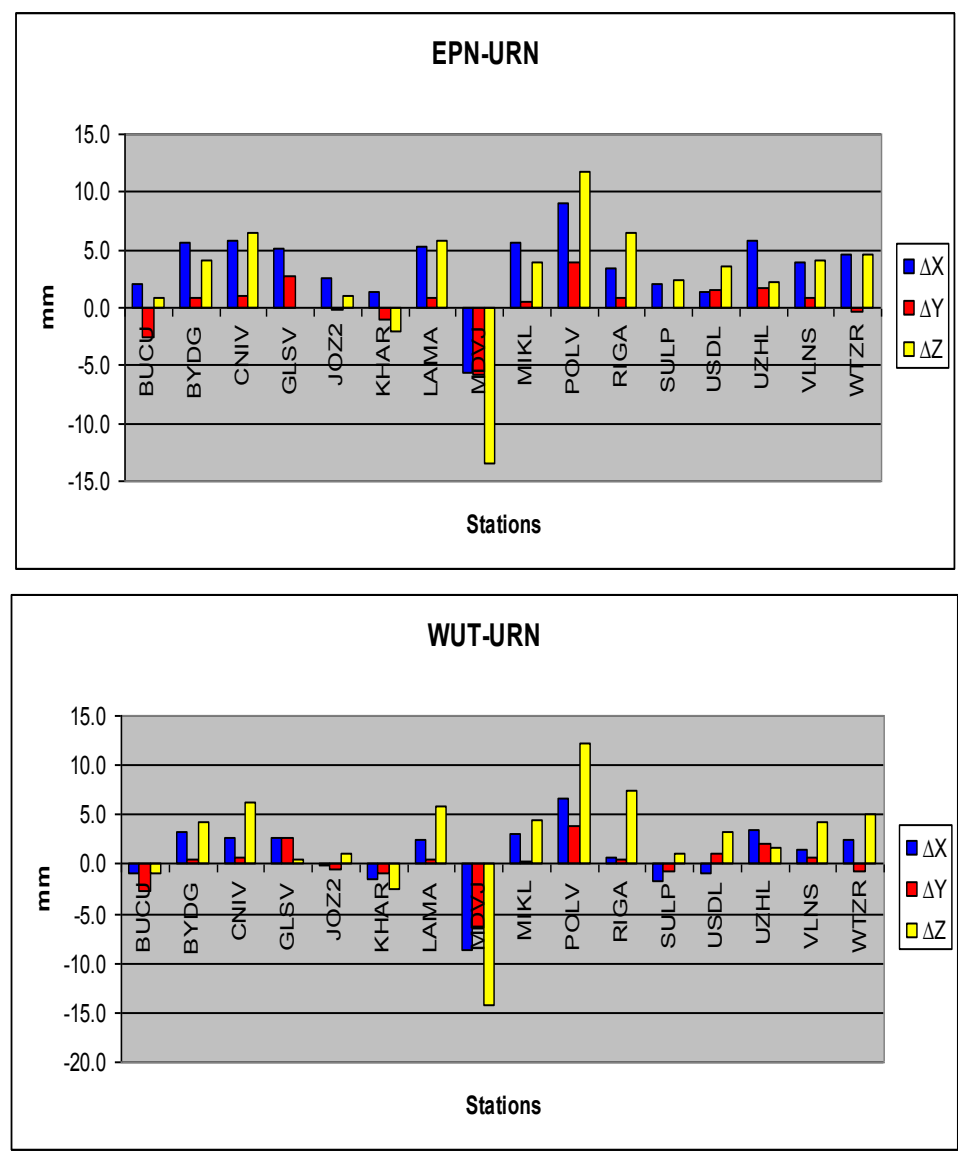

Figure 5. Differences between global (regional) and local networks solutions. Source: Authors.

The position differences between EPN and URN (WUT and URN) can reach 9.1 (6.6) $\mathrm{mm}$ for $\mathrm{X}, 4$ (3.8) $\mathrm{mm}$ for Y and 11.7 (12.2) $\mathrm{mm}$ for Z. These values we accept as an error caused by the network effect.

Table 3. Statistics (maximum, mean and RMS) of the differences between global (regional) and local solutions.

\begin{tabular}{|c|c|c|c|c|c|c|}
\hline \multirow{2}{*}{$\begin{array}{c}\text { Differences } \\
(\mathrm{mm})\end{array}$} & \multicolumn{3}{|c|}{ EPN-URN } & \multicolumn{3}{c|}{ WUT- URN } \\
\cline { 2 - 7 } & Max & Mean & RMS & Max & Mean & RMS \\
\hline $\mathrm{X}$ & 9.1 & 3.6 & 3.2 & 6.6 & 0.9 & 3.4 \\
\hline $\mathrm{Y}$ & 4.0 & 0.3 & 2.2 & 3.8 & 0.0 & 2.3 \\
\hline $\mathrm{Z}$ & 11.7 & 2.6 & 5.3 & 12.2 & 2.5 & 5.7 \\
\hline
\end{tabular}

Source: Authors. 
To obtain consistent station positions and velocities of local network without network effect, weekly solutions (1922 GPS week) for EPN (global network), EPN subnetwork processed by WUT LAC (regional network) and Ukraine reference network (local network) was combined. The combination was made by common stations. For approbation of the obtained results we calculated the difference between the combined solutions and EPN multi-year position and velocity solution (EPNm) [9] reduced to the same epoch (fig. 6).

Table 4. Statistics (maximum, mean and RMS) of the differences between multi-year and global (regional) and local combined solutions.

\begin{tabular}{|c|c|c|c|c|c|c|c|c|c|}
\hline Differences & \multicolumn{3}{|c|}{ EPNm-URN } & \multicolumn{3}{c|}{ EPNm-(URN+WUT) } & \multicolumn{3}{c|}{ EPNm-(URN+EPN) } \\
\hline$(\mathrm{mm})$ & Max & Mean & RMS & Max & Mean & RMS & Max & Mean & RMS \\
\hline $\mathrm{X}$ & 7.6 & 0.9 & 4.0 & 2.1 & 2.1 & 2.1 & 0.6 & -2.7 & 1.7 \\
\hline $\mathrm{Y}$ & 6.0 & 0.6 & 2.5 & 1.8 & 0.1 & 1.0 & 1.9 & 0.1 & 0.9 \\
\hline $\mathrm{Z}$ & 12.6 & 2.3 & 6.5 & 6.8 & 0.9 & 3.4 & 6.8 & 0.4 & 2.6 \\
\hline
\end{tabular}

Source: Authors.

These results show that by combining weekly solutions of the global, regional and local networks, the network effect can be largely eliminated from the local solution. This approach is successful due to the usage of the same processing strategy.

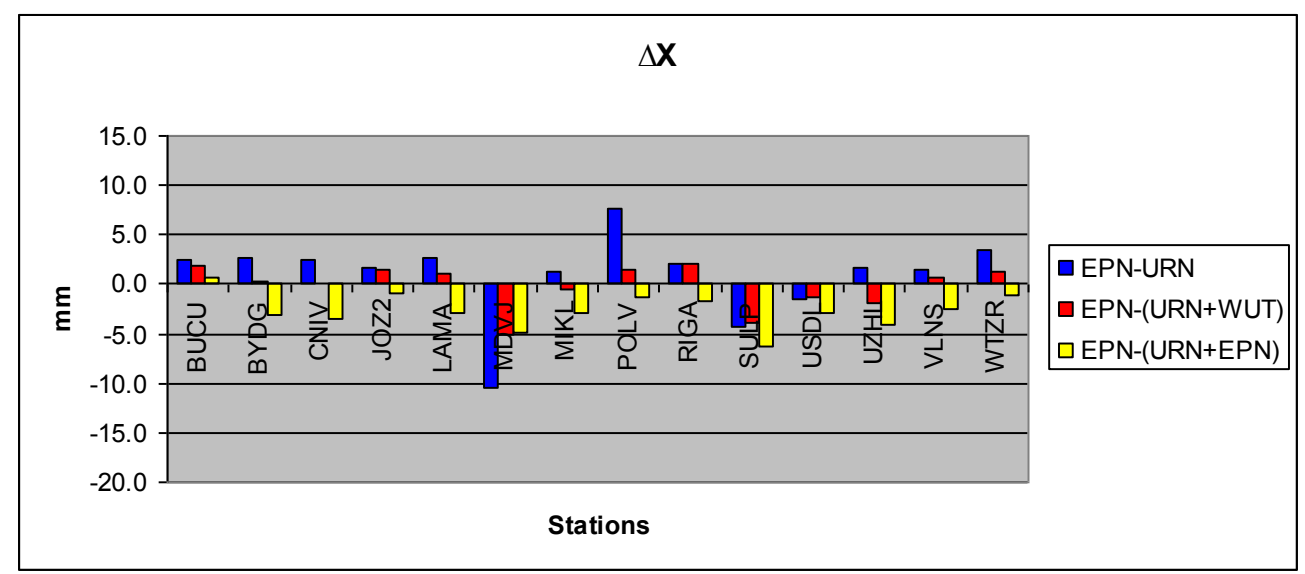



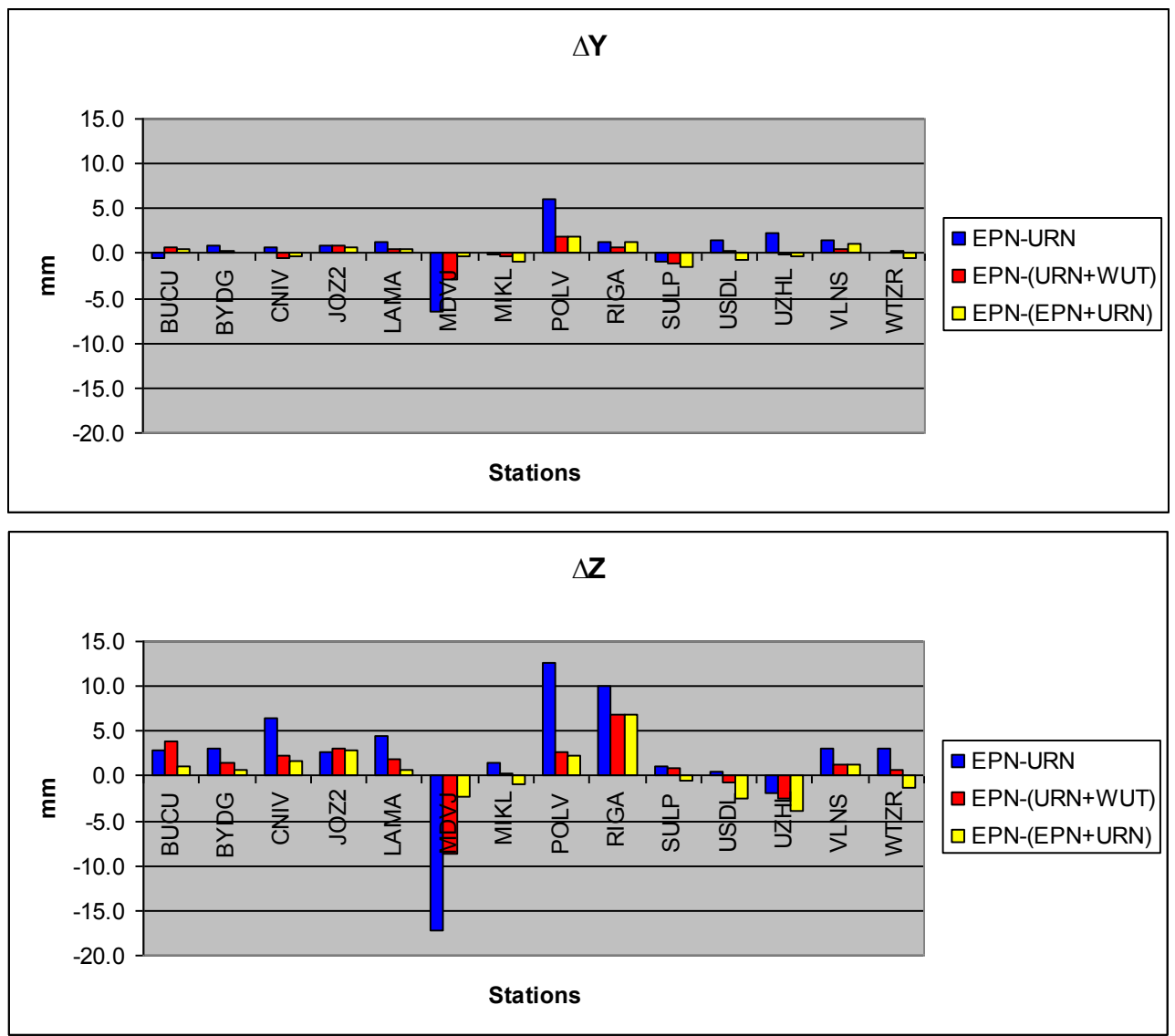

Fig. 6. Differences between EPN multi-year and global (regional) and local combined solutions. Source: Authors.

\section{CONCLUSIONS}

The authors have demonstrated how to remove network effect on position solution using data from different software. We investigated the differences between a local and a regional, a local and global GNSS network solutions which were estimated using an identical analysis strategy and tied to the ITRF2008 using minimum constraints. For positions differences reached $9.1 \mathrm{~mm}$ for X, $4 \mathrm{~mm}$ for $\mathrm{Y}$ and $12.2 \mathrm{~mm}$ for Z. To mitigate these differences global (regional) and local solutions were combined. This combination showed that the network effect on the local solution is largely eliminated. 


\section{REFERENCES}

[1] Altamimi Z.: Discussion on How to Express a Regional GPS Solution in the ITRF. EUREF Publication No. 12, Verlag des Bundesamtes für Kartographie und Geodäsie, Frankfurt am Main, 2003, pp. 162-167.

[2] Dach R., Hugentobler U., Fridez P., Meindl M.: Bernese GPS Software Version 5.0. Astronomical Institute, University of Bern, 2007.

[3] Herring T.A., King R.W., McClusky S.C.: GAMIT Reference Manual, GPS Analysis at MIT - Release 10.3. Department of Earth, Atmospheric, and Planetary Science MIT, 2009.

[4] Legrand J., Bruyninx C.: EPN Reference Frame Alignment: Consistency of the Station Positions. Bulletin of Geodesy and Geomatics, Vol. LXVIII, No.1, 2009, pp. 20-34.

[5] Legrand, J., Bruyninx C., Bergeot N.: Results and Comparisons of a Local and a Regional Reprocessed GNSS Network, Royal Observatory of Belgium, 2010. Available at: https://www.researchgate.net/publication/268409943 (access 16.07.2018).

[6] Legrand J., Bergeot N., Bruyninx C., Wöppelmann G., Bouin M-N., Altamimi Z., (2010) Impact of Regional Reference Frame Definition on Geodynamic Interpretations, Journal of Geodynamics, 2010, Vol. 49, Issues 3-4, pp. 116-122.

[7] http://www.epncb.oma.be/images/maps/EUREFDL.png (access 16.07.2018).

[8] http://www.epncb.oma.be/images/maps/WUT.png (access 16.07.2018).

[9] ftp://epncb.oma.be/epncb/station/coord/EPN/EPN_A_IGb08.SSC (access 16.07.2018).

Received October 2018

Reviewed December 2018

Accepted December 2018

JANUSZ ĆWIKLAK

Polish Air Force University

Dywizjonu 303 bldg. 35, 08-521 Dęblin, Poland

e-mail: j.cwiklak@law.mil.pl

\section{STEPAN SAVCHUK}

Polish Air Force University

Dywizjonu 303, bldg. 35, 08-521 Dęblin, Poland

e-mail: $\underline{\text { s.savchuk@law.mil.pl }}$

\section{SOFIYA DOSKICH}

Lviv Polytechnic National University

6 Karpinskyi str, bldg. 2, Lviv, Ukraine

e-mail: sofiia.v.doskich@1pnu.ua 


\section{STRESZCZENIE}

W celu zbadania i usunięcia efektu sieci do krajowej sieci GNSS porównano wyniki uzyskane z trzech sieci GNSS, które są związane z ITRF2008 przy użyciu minimalnych ograniczeń. Pierwsza, to sieć EUREF Permanent Network (EPN), druga to podsieć EPN nadzorowana przez Politechnikę Warszawską, trzecia to sieć referencyjna Ukrainy (URN). Różnice pozycji między tymi sieciami - EPN i URN oraz (PW i URN) mogą osiągnąć 9,1 $(6,6) \mathrm{mm}$ dla X, $4(3,8) \mathrm{mm}$ dla Y i 11,7 $(12,2) \mathrm{mm}$ dla Z. Aby uzyskać spójne pozycje stacji i prędkości bez efektu sieci, połączono dwa tygodniowe rozwiązania. Wyniki pokazują, że efekt sieci w lokalnym rozwiązaniu (ukraińska sieć) może zostać wyeliminowany. To podejście jest ważne, ponieważ podczas analizy badanych sieci zastosowano tę samą strategię obliczeniową. 